\title{
Assessment of Heavy Metals in Deep Groundwater Resources of the Kathmandu Valley, Nepal
}

\author{
Suman Man Shrestha', Kedar Rijal', Megh Raj Pokhrel² \\ ${ }^{1}$ Central Department of Environmental Science, Tribhuvan University, Kirtipur, Nepal \\ ${ }^{2}$ Central Department of Chemistry, Tribhuvan University, Kirtipur, Nepal \\ Email: sshrestha@cdes.edu.np
}

Received 24 December 2015; accepted 13 March 2016; published 17 March 2016

Copyright (C) 2016 by authors and Scientific Research Publishing Inc.

This work is licensed under the Creative Commons Attribution International License (CC BY). http://creativecommons.org/licenses/by/4.0/

(c) (i) Open Access

\begin{abstract}
A study was carried out to address distribution of some heavy metals in deep groundwater resources of the Kathmandu Valley. Groundwater samples were analyzed for pH, ORP, EC, iron, manganese, zinc, and arsenic in $\mathbf{4 1}$ deep groundwater wells during pre monsoon and post monsoon seasons for two consecutive years. The study showed elevated concentrations of iron and manganese in the groundwater of the valley. The occurrence of elevated concentrations of arsenic was also exhibited and observed up to $0.160 \mathrm{mg} / \mathrm{L}$. The spatial distribution patterns demonstrated elevated levels of EC, iron, manganese, zinc, and arsenic in central groundwater district (CGWD) of the valley. The monitored parameters except ORP are not significantly correlated with studied time series, inferring similar distribution of the metals. Correlation analysis and principal component analysis (PCA) were performed to find out relationships among examined parameters and metals. The ORP has strong negative correlations with iron, manganese, and arsenic, suggesting reductive mobilization mechanism of the metals in the groundwater. PCA results showed that iron and manganese with high positive loading factors were due to common natural source of origin of these metals in the groundwater, while negative loading factors of $\mathrm{pH}$ and $\mathrm{ORP}$ indicated that iron and manganese mobilization was favorable in low $\mathrm{pH}$ and reducing environment. Cluster analysis (CA) evidenced high mineralization in most of the wells in the CGWD.
\end{abstract}

\section{Keywords}

Heavy Metals, Deep Groundwater, Principal Component Analysis, Cluster Analysis, Mineralization 


\section{Introduction}

Heavy metals are commonly defined as those having a specific density of five times higher than water i.e., 5 $\mathrm{g} / \mathrm{cm}^{3}$ and denote metals and metalloids that are associated with pollution and toxicity. These also include elements that are required by organisms at rather low concentrations [1]-[3]. However, a heavy metal has little to do with density but concerns with chemical properties. The term heavy metal includes both essential and nonessential trace metals which may be toxic to the organisms depending on their own properties, availability (chemical speciation), and concentration levels [4]. Some heavy metals can become toxic or aesthetically undesirable when their concentrations are only too great. Heavy metals are very harmful because of their non-biodegradable nature, long biological half-lives, and their potential to accumulate in different body parts. The environmental exposure to heavy metals is a well-known risk factor for cancer [5]. The heavy metals and metalloids, including arsenic (As), manganese $(\mathrm{Mn})$, lead $(\mathrm{Pb})$, cadmium $(\mathrm{Cd})$, and mercury $(\mathrm{Hg})$, are potentially biohazardous, have their strong toxicity at even low concentrations, can accumulate in body tissues over long periods of time, and are nonessential for human health [1] [3] [4] [6].

Heavy metal contamination in groundwater either from natural or anthropogenic sources is one of the environmental issues due to its impact in public health [7]. The water supplies around the world possess serious problems due to enhanced heavy metal concentrations [8] [9]. The problems of groundwater pollution, especially from heavy metals have now raised concerns all over the world. The rapid growth of the Kathmandu Valley increases the demand of the water supply. The urbanization rate in the valley is very high. The decadal population growth rate in Kathmandu district is $61.23 \%$ [10]. Therefore, there is growing pressure on groundwater resources in the valley. Groundwater is one of the important water resources in the valley. It constitutes $60 \%$ $70 \%$ and about $50 \%$ of the total water supply during dry and wet seasons, respectively [11] [12].

Many investigators have carried out studies regarding heavy metals in the groundwater of the Kathmandu Valley. An earlier study carried out by Khadka [13] revealed that the deep groundwater contained high concentrations of iron and manganese. The occurrence of elevated concentrations of heavy metals has been detected in the deep groundwater [14]-[20]. However, there have been no long term studies concerning heavy metal contamination in the groundwater resources in the valley.

This study aimed to assess some heavy metals in deep groundwater wells of the Kathmandu Valley during pre monsoon and post monsoon seasons for two consecutive years. The spatial distribution patterns of the metals in northern groundwater district (NGWD), central groundwater district (CGWD), and southern groundwater district (SGWD) of the valley were investigated. Additionally, the study attempted to identify influential physicochemical parameters and metals using principal component analysis (PCA). Furthermore, the study was also focused on to classify groups of deep groundwater wells by performing multivariate hierarchical cluster analysis (CA) based on major groundwater quality parameters.

\section{Materials and Methods}

\subsection{Study Area}

The Kathmandu Valley is roughly circular in shape with diameter of about $25 \mathrm{~km}$ and an average altitude of $1300 \mathrm{~m}$ (above sea level), located in central Nepal Himalaya within $27^{\circ} 32^{\prime} \mathrm{N}$ to $27^{\circ} 49^{\prime} \mathrm{N}$ and $85^{\circ} 12^{\prime} \mathrm{E}$ to $85^{\circ} 32^{\prime} \mathrm{E}$ (Figure 1). Its surrounding hills are approximately $2800 \mathrm{~m}$ (above sea level). The area of the valley is about 650 $\mathrm{km}^{2}$. The valley comprises of Kathmandu, Lalitpur, and Bhaktapur districts. Kathmandu is the largest and the capital city of Nepal.

The Kathmandu Valley is an intermontane basin filled with Pliocene-quaternary fluvio-lacustrine unconsolidated sediments which is up to $500 \mathrm{~m}$ thick [21]. Limestones are abundant to the south, whereas to the east and west, the valley is bordered by phyllites and siltstones. Granite gneisses are located on the northern border of the valley [22].

On the basis of hydrochemical and hydrogeological studies, JICA [23] divided the deep groundwater of the Kathmandu Valley into three groundwater districts: NGWD, CGWD, and SGWD. The NGWD has greater potentialities for recharge of the groundwater and is the main aquifer in the valley. About $60 \mathrm{~m}$ thick of highly permeable micaceous quartz, sand, and gravel are main upper deposits of the groundwater district. The upper deposits in the CGWD are covered by impermeable thick stiff black clay, named as Kalimati Formation which is rich in organic matter. The groundwater recharge is limited by the presence of the black clay layer in the 


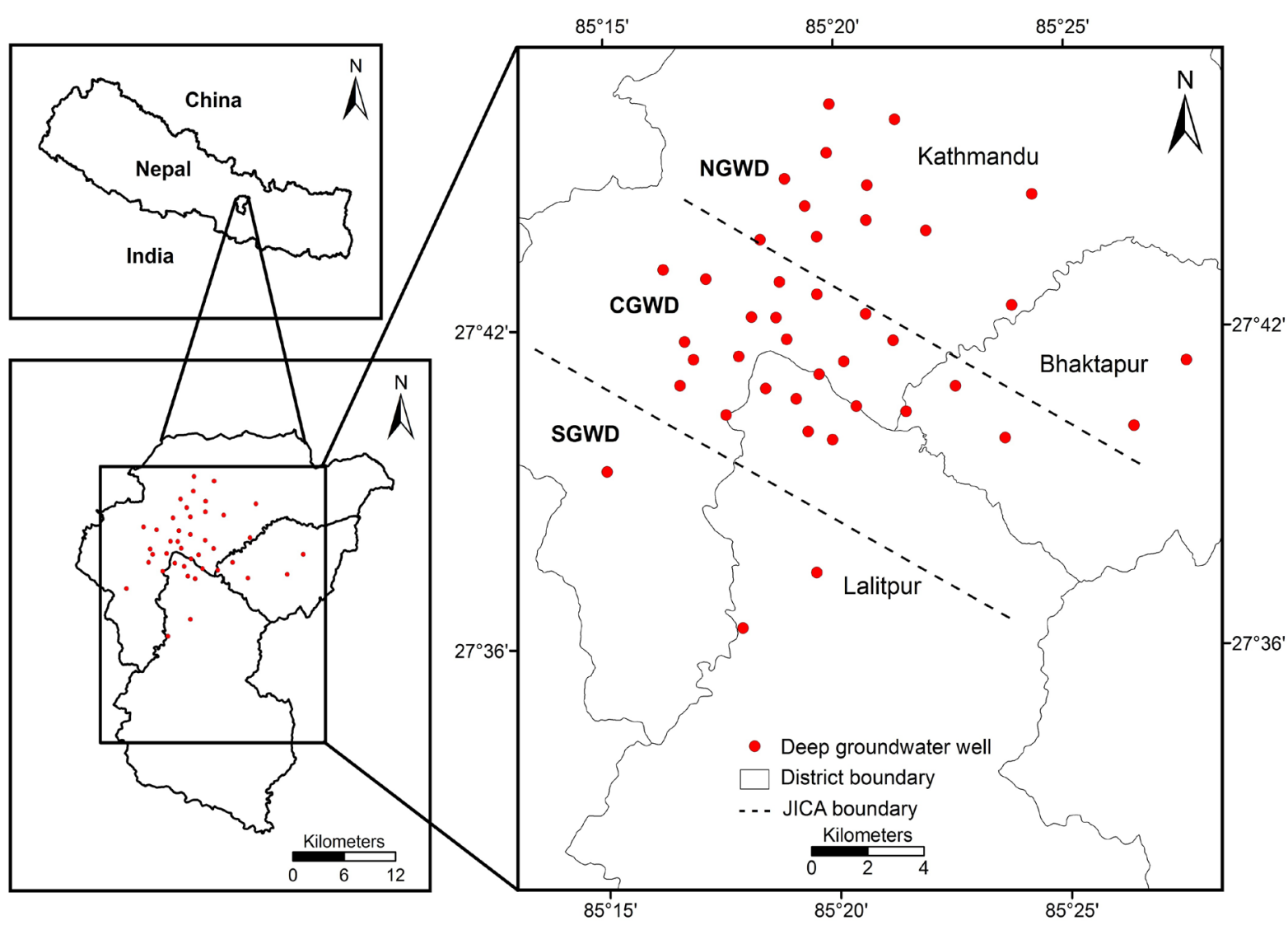

Figure 1. Sampling locations in the study area.

CGWD. The major deposits in the SGWD are thick impermeable clays and basal gravels with low permeability. Conversely, there are sand and gravel deposits in some parts of the eastern area of the SGWD which has a potential for groundwater recharge [23]-[25].

\subsection{Sampling and Analysis of Groundwater}

The samples were collected from 41 deep groundwater wells during pre monsoon and post monsoon seasons in 2012 and 2013 (Figure 1). The depth of the groundwater wells was varied from 84 to $304 \mathrm{~m}$. The high density polyethylene (HDPE) sampling bottles treated with $5 \% \mathrm{HNO}_{3}$ and rinsed with double distilled water were used for sample collection. The samples were collected after pumping the wells for five minutes to get the representative samples. The samples for total iron, total manganese, and total zinc were preserved by adding $1.5 \mathrm{~mL} / \mathrm{L}$ of conc. $\mathrm{HNO}_{3}$. The samples for total arsenic were preserved with $2 \mathrm{~mL} / \mathrm{L}$ conc. $\mathrm{HNO}_{3}$. The groundwater samples for metals were brought to the laboratory and stored at temperature below $4{ }^{\circ} \mathrm{C}$ before chemical analysis. Oxidation reduction potential (ORP), electrical conductivity (EC), $\mathrm{pH}$, and temperature (T) were measured in the fields. The ORP and pH were measured by Hanna HI 8314 pH/ORP meter and the EC was measured by Jenway 4200 conductivity meter. The total iron, total manganese, and total zinc were analyzed by Varian AA 240 atomic absorption spectrometer (AAS). The analysis of arsenic was carried out using the AAS with vapor generation accessory Varian VGA-77. The samples for total iron, total manganese, total zinc, and total arsenic were digested with high purity $\mathrm{HNO}_{3}$ (Merck) within a week of sample collection as per APHA-AWWA-WEF (2005) [26]. The digestion of samples with the $\mathrm{HNO}_{3}$ ensures total extraction of the metals. The metal standard solutions for AAS (Merck) traceable to standard reference material (SRM) of NIST (National Institute of Standards and Technology, Gaithersburg, MD, USA) were used for preparation of calibration solutions. Three replications of each analysis were performed and mean values were used for calculations. Analytical precision was in good agreement, generally better than 5\% RSD. The analyses of the metals were carried out at CEMAT Water Labor- 
atory, Kathmandu, Nepal. Statistical packages PASW STATISTICS 18.0 for WINDOWS (SPSS Inc., an IBM Company, Chicago, IL, USA, 2009) and Microsoft Office-Excel 2007 (Redmond, WA, USA) were used for the statistical analyses. ArcGIS 9.3 was used for mapping and spatial analysis.

\subsection{Statistical Treatment of Data and Multivariate Analysis}

Shapiro-Wilk test was performed to test the goodness of fit of data to normal distribution. Most of the water quality parameters examined were not normally distributed except temperature. Therefore, Spearman's rank correlation coefficient was applied as a non-parametric measure of correlation between the monitored variables [19] [27]. Kaiser-Meyer-Olkin (KMO) and Bartlett's test were employed to examine the suitability of data for $\mathrm{PCA}$. The KMO is a measure of sampling adequacy that indicates the proportion of variance (common variance) which might be caused by underlying factors. High value (close to 1 ) generally indicates that PCA analysis may be useful [28].

PCA is an effective pattern recognition technique in multivariate analysis that attempts to explain the variance of a data set of inter-correlated variables with a smaller set of independent variables, principal components (PCs). PCA was performed on the normalized data to compare the monitored groundwater quality variables and to identify the factors that influence each other. The PCs were identified with eigen value $>1.0$ and factor loading matrix was calculated on the basis of the variables. The application of multivariate statistical technique assists to simplify and organize large data sets by data reduction and interpretation of the variables [29]-[31]. The multivariate statistical techniques were performed on experimental data standardized through z-scale transformation in order to avoid misclassification emerged from wide differences in the dimension of data both numerical values and variance of the variables [32] [33]. The standardization process makes different units of data dimensionless [34], thereby increase or decrease influence of variables whose variance is small or large, respectively [28].

Varimax rotation is used to maximize the variance of the extracted principal axes [35]. The factor-loading matrix is rotated to an orthogonal simple structure through the axis defined by PCA is a varimax rotation which results in varifactors (VFs). The varimax rotation reduces the contribution of less significant variables obtained from PCA increasing the participation of the variables with higher contribution [32] [36].

Multivariate statistical analysis, CA is applied to detect the similarity among different sampling sites. In this study, hierarchical CA was applied and the data were treated after data scaling by z-scale transformation, and Ward's method of linkage with squared Euclidean distance as measure of similarity was used. The clustering procedure generates either cluster or groups based on similar characteristics. The results indicate that CA technique is useful in offering reliable classification of groundwater resources in the study area and are used to find the true groups of data. Dendrogram is constructed on the basis of the levels of the similarity [37].

\section{Results and Discussion}

\subsection{Monitored Groundwater Quality Parameters}

The mean of values monitored groundwater quality parameters and the summary of statistical data during pre monsoon and post monsoon of 2012 and 2013 in the groundwater wells are presented in Table 1 and Table 2, respectively. The $\mathrm{pH}$ were nearly neutral that ranged from 6.3 to 7.9 (mean $=6.8$ ). The EC ranged from 92 to $1729 \mu \mathrm{S} / \mathrm{cm}$ (mean $=572 \mu \mathrm{S} / \mathrm{cm})$.

Many groundwater wells in the study area contained elevated iron and manganese concentrations. The mean iron and manganese concentration were $3.75 \mathrm{mg} / \mathrm{L}$ and $0.44 \mathrm{mg} / \mathrm{L}$, respectively. The groundwater wells were under reduced conditions as indicated by low ORP values which ranged from -190 to $135 \mathrm{mV}$ (mean $=-61.3$ $\mathrm{mV}$ ). In an anaerobic environment, reduction of arsenic and Fe/Mn oxyhydroxides would lead to desorption of arsenic, and release of $\mathrm{Fe}(\mathrm{II})$ and $\mathrm{Mn}(\mathrm{II})$ [38]-[40]. In addition, the chemical composition of the major elements of the sediments: $\mathrm{Fe}_{2} \mathrm{O}_{3}$ ranged from 1.48 to $9.55 \mathrm{wt} \%$ and $\mathrm{MnO}$ ranged from 0.01 to $0.18 \mathrm{wt} \%$ in the Kathmandu Valley [41] could be related to occurrence of elevated concentration of iron and manganese in the groundwater. Zinc concentration in the study area is relatively lower that ranged from $<0.003$ to $0.951 \mathrm{mg} / \mathrm{L}$ (mean $=0.065 \mathrm{mg} / \mathrm{L}$ ).

This study revealed a wide variation of arsenic concentrations in the deep groundwater which ranged from 
Table 1. Mean values of monitored groundwater quality parameters during pre monsoon and post monsoon of 2012-2013.

\begin{tabular}{|c|c|c|c|c|c|c|c|c|}
\hline $\begin{array}{l}\text { Well } \\
\text { ID }\end{array}$ & $\mathrm{pH}$ & $\mathrm{EC}(\mu \mathrm{S} / \mathrm{cm})$ & ORP (mV) & $\mathrm{T}\left({ }^{\circ} \mathrm{C}\right)$ & $\mathrm{Fe}(\mathrm{mg} / \mathrm{L})$ & $\mathrm{Mn}(\mathrm{mg} / \mathrm{L})$ & $\mathrm{Zn}(\mathrm{mg} / \mathrm{L})$ & As (mg/L) \\
\hline 1 & 7.1 & 649 & -152 & 23.8 & 0.90 & 0.17 & 0.020 & BDL \\
\hline 2 & 7.3 & 511 & -116 & 25.0 & 1.61 & 0.23 & 0.041 & 0.143 \\
\hline 3 & 6.6 & 958 & -105 & 25.2 & 6.41 & 0.81 & 0.043 & 0.015 \\
\hline 4 & 7.2 & 403 & -81 & 23.2 & 2.15 & 0.23 & 0.057 & 0.056 \\
\hline 5 & 7.8 & 165 & 106 & 21.9 & 0.06 & BDL & 0.029 & BDL \\
\hline 6 & 6.6 & 1122 & -71 & 24.1 & 4.14 & 1.50 & 0.020 & 0.012 \\
\hline 7 & 6.5 & 800 & -81 & 26.0 & 6.86 & 0.77 & 0.647 & 0.011 \\
\hline 8 & 6.9 & 1041 & -113 & 25.7 & 4.14 & 0.89 & 0.060 & 0.007 \\
\hline 9 & 6.6 & 1051 & -83 & 26.5 & 3.80 & 0.55 & 0.075 & 0.007 \\
\hline 10 & 6.4 & 482 & 104 & 21.4 & 0.29 & 0.70 & 0.494 & BDL \\
\hline 11 & 6.8 & 185 & -58 & 23.7 & 1.51 & 0.16 & 0.018 & 0.003 \\
\hline 12 & 6.7 & 393 & -74 & 24.4 & 4.43 & 0.25 & 0.031 & 0.005 \\
\hline 13 & 6.7 & 751 & -88 & 24.6 & 4.83 & 0.38 & 0.026 & 0.007 \\
\hline 14 & 6.5 & 326 & -70 & 21.5 & 6.66 & 0.30 & 0.025 & $\mathrm{BDL}$ \\
\hline 15 & 6.8 & 186 & -58 & 25.0 & 0.97 & 0.13 & 0.019 & 0.004 \\
\hline 16 & 6.6 & 225 & -53 & 24.4 & 1.38 & 0.19 & 0.051 & 0.006 \\
\hline 17 & 6.7 & 193 & -72 & 23.9 & 1.60 & 0.19 & 0.011 & 0.004 \\
\hline 18 & 6.7 & 462 & -67 & 24.9 & 2.63 & 0.19 & 0.019 & 0.006 \\
\hline 19 & 6.6 & 408 & -86 & 27.1 & 2.20 & 0.45 & 0.012 & 0.011 \\
\hline 20 & 6.6 & 232 & -67 & 23.6 & 2.38 & 0.20 & 0.012 & 0.008 \\
\hline 21 & 6.5 & 923 & -97 & 24.3 & 6.27 & 1.08 & 0.043 & 0.011 \\
\hline 22 & 6.6 & 757 & -99 & 25.9 & 6.70 & 0.77 & 0.017 & 0.037 \\
\hline 23 & 6.5 & 902 & -94 & 25.6 & 7.21 & 1.08 & 0.013 & 0.009 \\
\hline 24 & 7.1 & 441 & -114 & 22.2 & 4.87 & 0.66 & 0.053 & 0.019 \\
\hline 25 & 6.5 & 985 & -118 & 24.8 & 7.95 & 0.61 & 0.040 & 0.006 \\
\hline 26 & 6.6 & 1707 & -114 & 25.4 & 8.08 & 0.26 & 0.023 & 0.003 \\
\hline 27 & 6.8 & 882 & -102 & 23.1 & 5.02 & 0.46 & 0.060 & 0.056 \\
\hline 28 & 6.5 & 1097 & -107 & 25.0 & 7.22 & 1.10 & 0.018 & 0.010 \\
\hline 29 & 6.6 & 1300 & -102 & 24.9 & 5.42 & 0.44 & 0.049 & 0.004 \\
\hline 30 & 7.1 & 764 & -143 & 23.3 & 3.69 & 0.46 & 0.032 & 0.025 \\
\hline 31 & 6.9 & 439 & -58 & 25.1 & 1.89 & 0.29 & 0.025 & 0.004 \\
\hline 32 & 6.5 & 246 & -66 & 22.1 & 5.11 & 0.35 & 0.019 & BDL \\
\hline 33 & 6.7 & 169 & -40 & 21.5 & 1.19 & 0.11 & 0.017 & 0.003 \\
\hline 34 & 6.5 & 615 & -87 & 25.3 & 5.34 & 0.45 & 0.019 & 0.005 \\
\hline 35 & 6.7 & 95 & 38 & 21.6 & 0.52 & 0.02 & 0.022 & BDL \\
\hline 36 & 6.9 & 150 & -42 & 22.3 & 1.01 & 0.05 & 0.100 & BDL \\
\hline 37 & 7.0 & 167 & -69 & 24.6 & 3.25 & 0.13 & 0.015 & 0.003 \\
\hline 38 & 7.5 & 587 & 84 & 26.6 & 0.11 & 0.04 & 0.027 & BDL \\
\hline 39 & 7.6 & 207 & 81 & 18.4 & 0.07 & BDL & 0.093 & BDL \\
\hline 40 & 7.0 & 297 & 104 & 22.0 & 2.50 & 0.85 & 0.237 & BDL \\
\hline 41 & 6.8 & 185 & -85 & 21.1 & 11.42 & 0.53 & 0.011 & BDL \\
\hline
\end{tabular}

$\mathrm{BDL}=$ Below detection limit. 
Table 2. Summary of statistical data for monitored groundwater quality parameters.

\begin{tabular}{ccccccc}
\hline Variable & Unit & Min. & Max. & Median & Mean & SD \\
\hline $\mathrm{pH}$ & & 6.3 & 7.9 & 6.7 & 6.8 & 0.35 \\
$\mathrm{EC}$ & $\mathrm{\mu S} / \mathrm{cm}$ & 92 & 1729 & 461 & 572 & 381 \\
$\mathrm{ORP}$ & $\mathrm{mV}$ & -190 & 135 & -82 & -61.3 & 70.1 \\
$\mathrm{~T}$ & ${ }^{\circ} \mathrm{C}$ & 16.8 & 28.6 & 23.9 & 23.9 & 2.27 \\
$\mathrm{Fe}$ & $\mathrm{mg} / \mathrm{L}$ & $\mathrm{BDL}$ & 12.99 & 3.15 & 3.75 & 2.81 \\
$\mathrm{Mn}$ & $\mathrm{mg} / \mathrm{L}$ & $\mathrm{BDL}$ & 1.75 & 0.34 & 0.44 & 0.37 \\
$\mathrm{Zn}$ & $\mathrm{mg} / \mathrm{L}$ & $\mathrm{BDL}$ & 0.951 & 0.026 & 0.065 & 0.186 \\
$\mathrm{As}$ & $\mathrm{mg} / \mathrm{L}$ & $\mathrm{BDL}$ & 0.160 & 0.005 & 0.013 & 0.024 \\
\hline
\end{tabular}

Min. $=$ Minimum, Max. $=$ Maximum, SD = Standard deviation, BDL = Below detection limit.

$<0.003$ to $0.160 \mathrm{mg} / \mathrm{L}$; the mean concentration being $0.013 \mathrm{mg} / \mathrm{L}$. Arsenic concentration in about $27 \%$ of the examined wells exceeded World Health Organization (WHO) guideline value for drinking water of $0.010 \mathrm{mg} / \mathrm{L}$ [42]. Arsenic concentration in the sediments of the valley averages $8 \mathrm{mg} / \mathrm{kg}$ (ranging from 3 to $25 \mathrm{mg} / \mathrm{kg}$ ) [43] could be the probable source of arsenic in the groundwater. The widespread lacustrine clay in the valley is rich in organic matter [44]. The presence of organic matter results in the reduction of iron and manganese in groundwater [45]. Arsenic is either adsorbed into the surface or coprecipitated in Fe/Mn oxyhydroxides [39] [46] and its dissolution or desorption in reducing environment was observed by many researchers [47]-[50]. Several investigators have reported the elevated arsenic concentrations in the groundwater of the Kathmandu Valley [15] [16] [18] [20].

The temporal variation of the monitored physicochemical parameters and metals during pre monsoon and post monsoon seasons of 2012 and 2013 were evaluated through time-parameter Spearman's correlation matrix. The parameters were not significantly $(\mathrm{p}>0.05)$ correlated with studied time series except for ORP $(\mathrm{r}=0.262, \mathrm{p}<$ 0.01 ), implying that there is no temporal variation of $\mathrm{pH}, \mathrm{EC}$, iron, manganese, zinc, and arsenic in the groundwater.

Spearman's rank correlation coefficients were determined to establish the relationships of monitored parameters in the groundwater (Table 3). The $\mathrm{pH}$ has strong negative correlations with iron and manganese, which can be explained by dissolution of the metals in acidic media. The $\mathrm{pH}$ has no significant correlation with zinc. Zinc is one of the most mobile heavy metals in groundwater because it is available as soluble compounds at neutral and acidic $\mathrm{pH}$ values. At higher $\mathrm{pH}$ values, zinc can form carbonate and hydroxide complexes which control

Table 3. Spearman's rank correlation coefficients of monitored groundwater quality parameters $(\mathrm{n}=164)$.

\begin{tabular}{|c|c|c|c|c|c|c|c|}
\hline Parameter & pH & EC & ORP & $\mathbf{F e}$ & Mn & Zn & As \\
\hline pH & 1.000 & & & & & & \\
\hline EC & $-0.286^{* *}$ & 1.000 & & & & & \\
\hline ORP & -0.001 & $-0.589^{* *}$ & 1.000 & & & & \\
\hline $\mathrm{Fe}$ & $-0.472^{* *}$ & $0.576^{* *}$ & $-0.566^{* *}$ & 1.000 & & & \\
\hline Mn & $-0.395^{* *}$ & $0.682^{* *}$ & $-0.404^{* *}$ & $0.677^{* *}$ & 1.000 & & \\
\hline Zn & 0.121 & $0.211^{* *}$ & 0.011 & -0.068 & 0.135 & 1.000 & \\
\hline As & -0.032 & $0.477^{* *}$ & $-0.512^{* *}$ & $0.375^{* *}$ & $0.468^{* *}$ & 0.096 & 1.000 \\
\hline
\end{tabular}

\footnotetext{
${ }^{* *}$ Significant value at $p<0.01$.
} 
zinc solubility [51]. Arsenic has weak negative correlation with the $\mathrm{pH}$. On the contrary, many investigators have observed positive correlation between arsenic and $\mathrm{pH}$ in groundwater, which is probably due to desorption processes at higher $\mathrm{pH}$ values [52]-[54]. In this study, the weak negative correlation indicates that there is minimal effect of $\mathrm{pH}$ in release of arsenic. Arsenic is positively correlated with iron and manganese, suggesting common geogenic origin of these metals. The ORP has strong negative correlations with iron, manganese, and arsenic, which is attributed to the release of these metals in reducing environment in the groundwater. Zinc has no significant correlation with ORP.

\subsection{Spatial Distribution of Major Monitored Groundwater Quality Parameters}

The spatial distribution patterns of major groundwater quality parameters including iron, manganese, zinc, and arsenic are illustrated in Figures 2-7. Most of the groundwater wells of the CGWD exhibited higher concentrations of metals and EC value, and lower ORP value. The elevated concentrations of the metals are attributed to the reducing environment in the CGWD. In addition, the contents of $\mathrm{Fe}_{2} \mathrm{O}_{3}$ in the sediments are generally high (ranges $<0.5$ to $15 \mathrm{wt} \%$ ), and are uniformly higher in the fine sediments of the central basin (average $7 \mathrm{wt} \%$ ) [55]. Though, the concentrations of zinc are lower in all the examined groundwater wells, the spatial distribution pattern of zinc reveals that few groundwater wells in the CGWD exhibited relatively higher concentrations, indicating that the higher zinc abundances in fine-grained sediments. Zinc abundances are $<10 \mathrm{mg} / \mathrm{kg}$ in most sand and gravel sediments, whereas in the fine-grained sediments (e.g., silty clay) are relatively higher (up to 94 $\mathrm{mg} / \mathrm{kg}$ ) [43]. Many groundwater wells in the NGWD and SGWD have lower iron, manganese, and arsenic concentrations. The finer particles and trace elements in the sediments of the central part of the valley are high [43]. The decrease in grain size tends to increase the concentration of metals in the sediments [43] [56] [57], because smaller particles in the sediments collectively hold larger surface area available for the formation of metal hydroxide coatings and to adsorb metal ions. Therefore, variation in grain size has an important role in the mobilization of metals in groundwater.

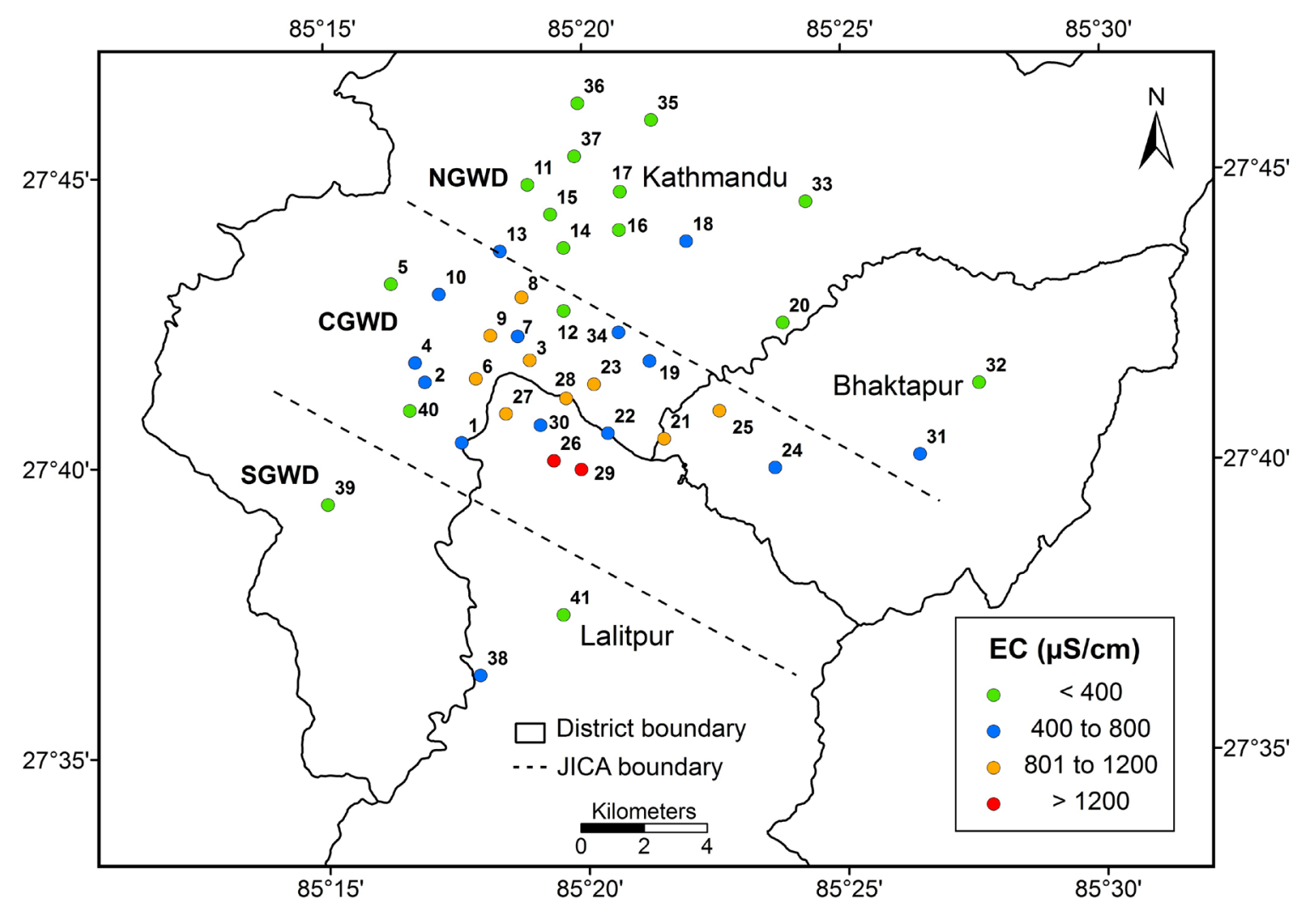

Figure 2. Spatial distribution pattern of EC. 


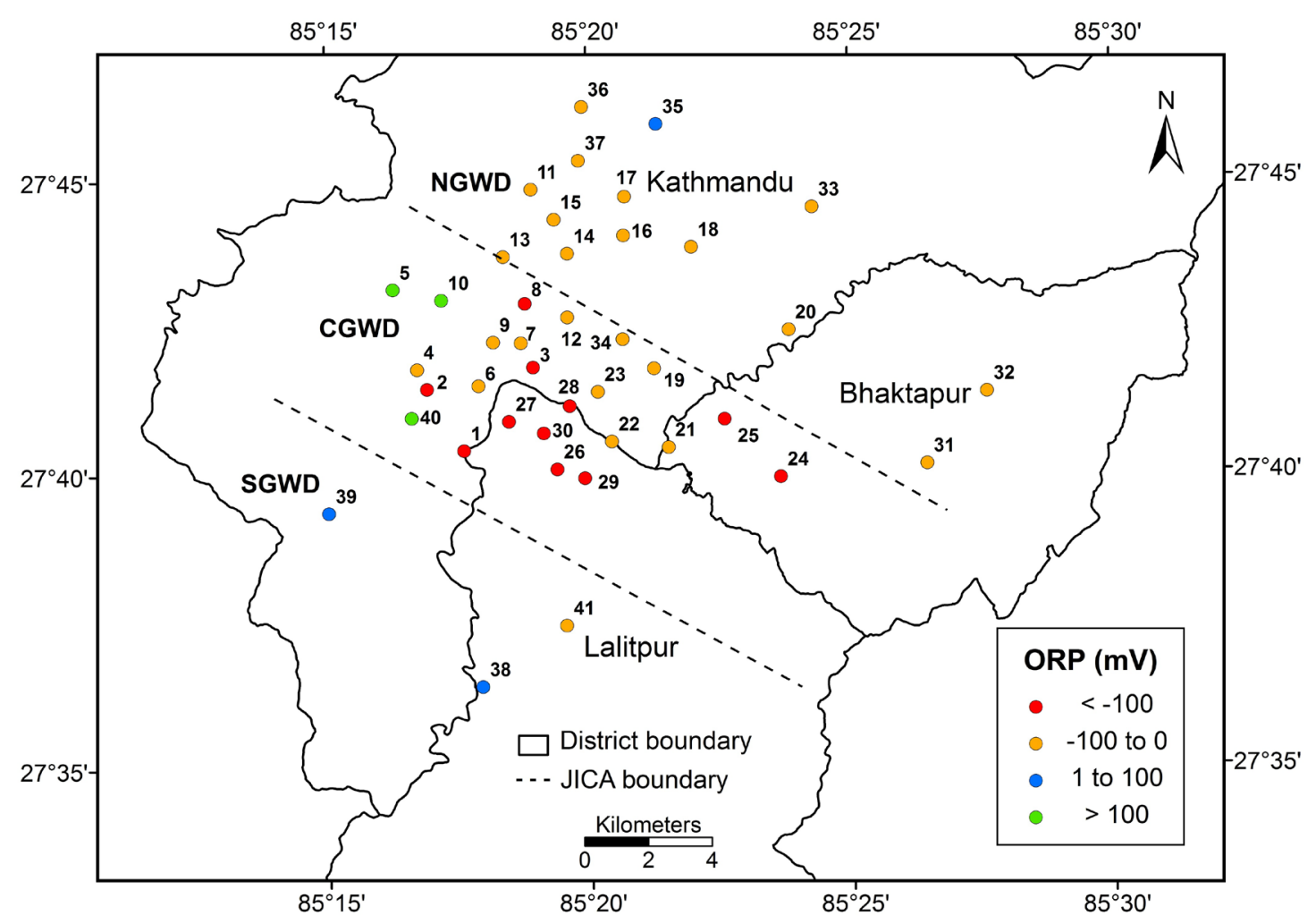

Figure 3. Spatial distribution pattern of ORP.

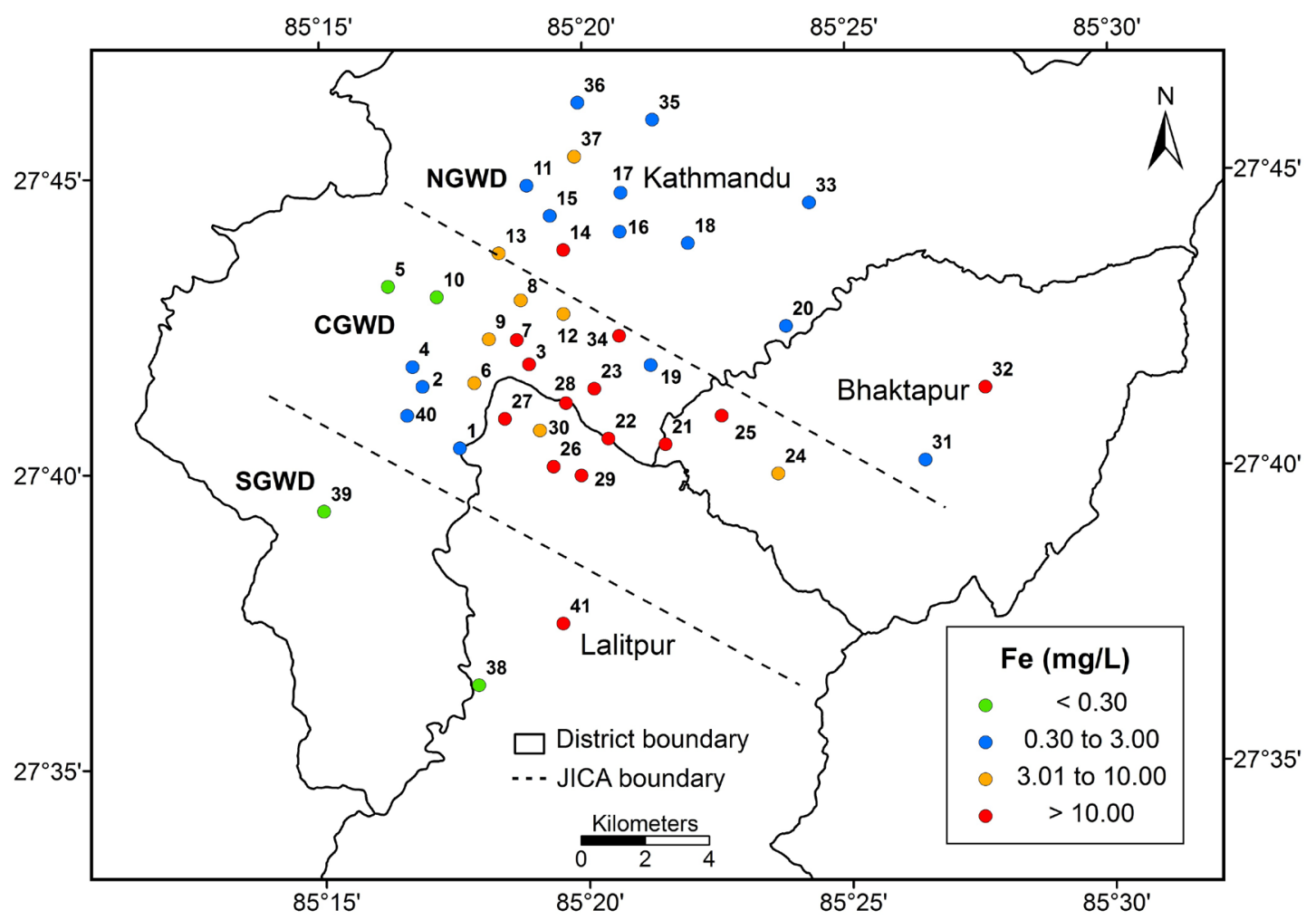

Figure 4. Spatial distribution pattern of iron. 


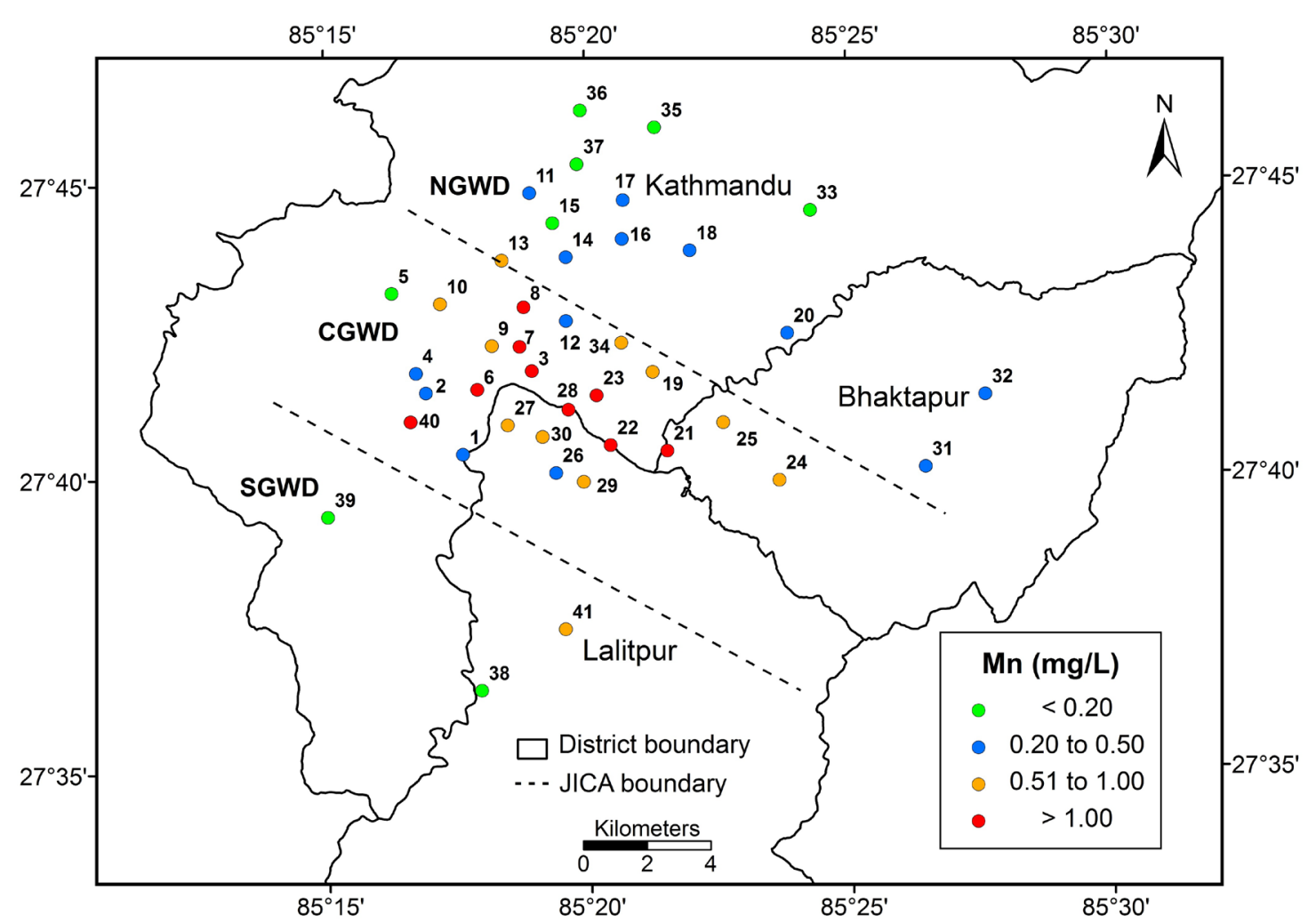

Figure 5. Spatial distribution pattern of manganese.

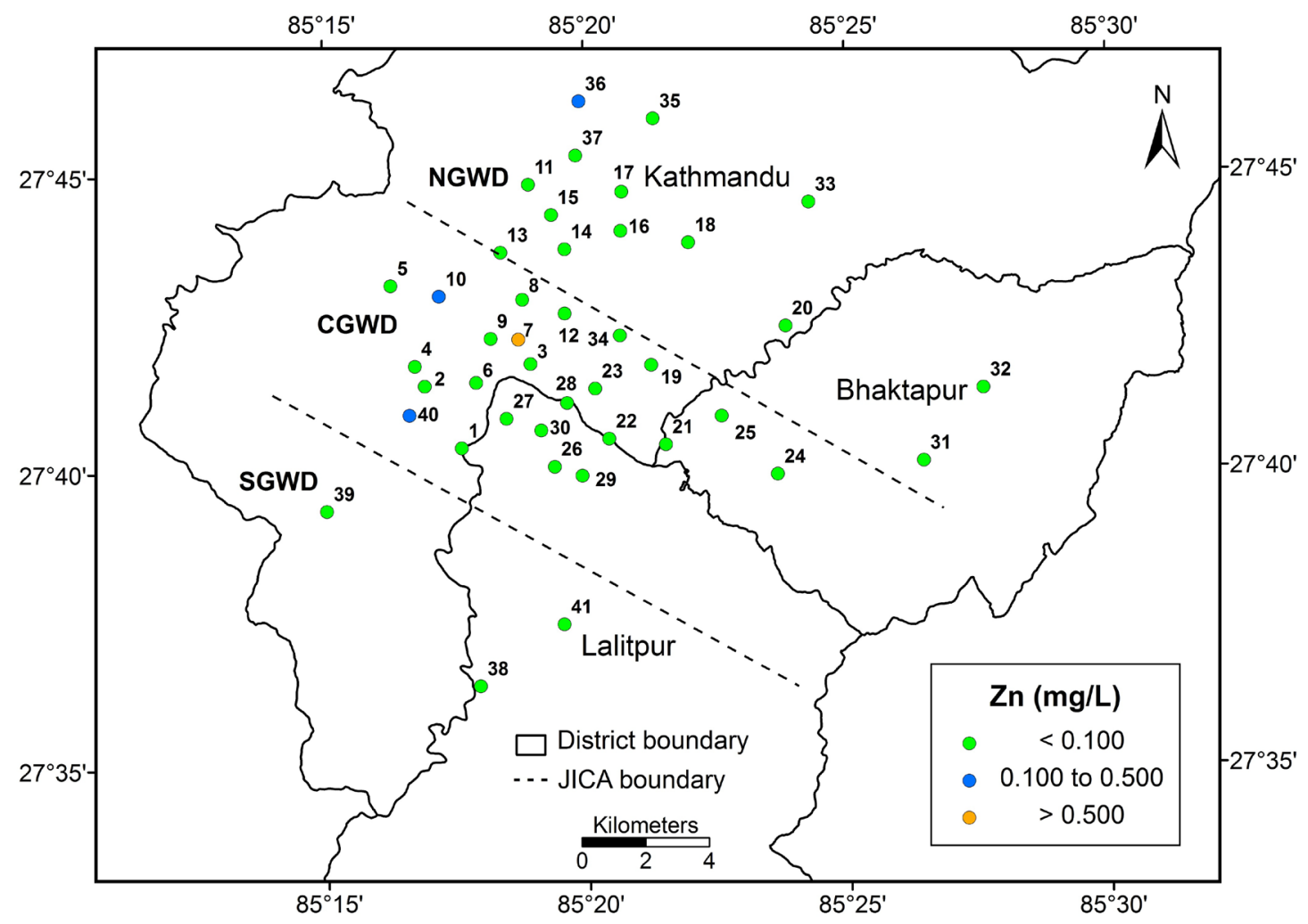

Figure 6. Spatial distribution pattern of zinc. 


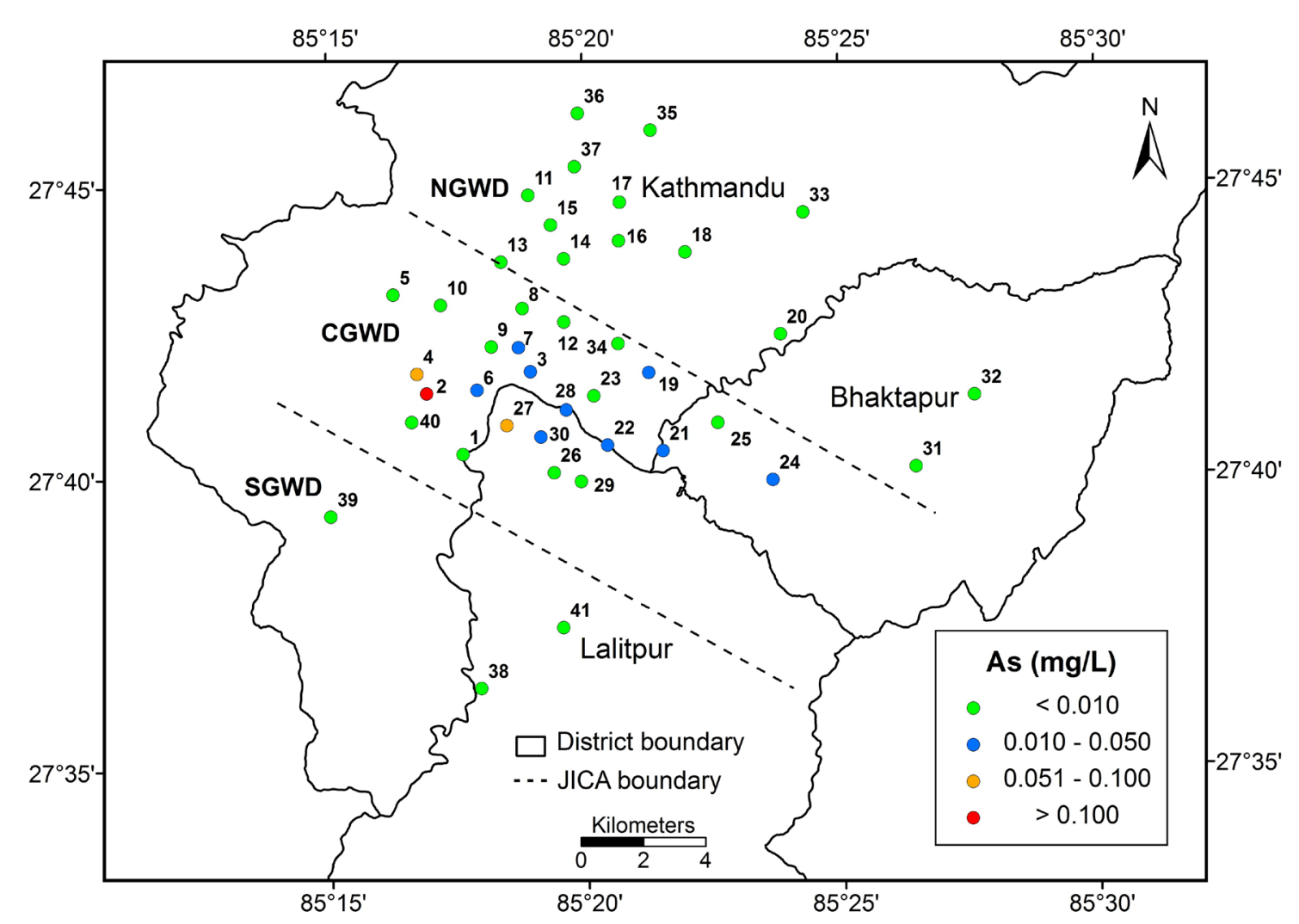

Figure 7. Spatial distribution pattern of arsenic.

\subsection{Principal Component Analysis}

The KMO measure of sampling adequacy was 0.682 , which shows that PCA analysis is useful in data interpretation and analysis. Bartlett's test of sphericity was significant $(\mathrm{p}<0.05)$, indicating that PCA can achieve significant reduction in the dimensionality of the original data set [32]. In the groundwater wells, VFs were indentified with eigen value $>1.0$, accounting almost $73.6 \%$ of the total variance, and factor loading matrix is calculated on the basis of the groundwater quality parameters measured during pre monsoon and post monsoon in 2012 and 2013 (Table 4). In the first VF, 38.8\% of the total variance is contributed by positive loadings of EC, iron, and manganese. The contribution of EC is indicated by its high loading factor and is due to the presence of dissolved ions. The high loading factors of iron and manganese reveals that these metals have common natural source of origin in the groundwater. The concentrations of iron and manganese in the groundwater are more likely due to the dissolution and weathering process of the minerals. Additionally, moderate negative loading factors of $\mathrm{pH}$ and ORP indicate that iron and manganese mobilization is favorable in low $\mathrm{pH}$ and reducing environment. Reducing environment is responsible for the release of iron and manganese, and $\mathrm{Fe} / \mathrm{Mn}$ oxyhydroxide precipitation and its ability to adsorb metals are the major controlling factors that lead to metal contents in groundwater [58]. This may exhibit the influence of geochemical processes and hydrodynamic behavior of iron and manganese in groundwater. The second VF accounting for $19.8 \%$ of total variance is contributed by high loading factor of zinc and moderate loading factor of ORP. In oxidizing environment, dissolution of zinc is favorable and it readily precipitates under reducing conditions [51]. The third VF contributing for $15.0 \%$ of total variance is contributed by strong positive loading factor of arsenic. This VF represents only arsenic, which indicates that mobilization of arsenic in groundwater is distinctive and can be related to reduction of $\mathrm{Fe} / \mathrm{Mn}$ oxyhydroxides.

\subsection{Cluster Analysis}

In the present study, CA is based on the major groundwater quality parameters of the deep groundwater samples. Hierarchical CA was performed to construct dendrogram (Figure 8). CA classified two statistically significant 
Table 4. Loadings of monitored variables of first three rotated principal components (varifactors) $(\mathrm{n}=164)$.

\begin{tabular}{cccc}
\hline Variables & VF 1 & VF 2 & VF 3 \\
pH & -0.620 & -0.043 & 0.495 \\
EC & 0.791 & 0.016 & 0.141 \\
ORP & -0.636 & 0.538 & -0.248 \\
Fe & 0.824 & -0.148 & -0.114 \\
Mn & 0.772 & 0.306 & 0.004 \\
Zn & 0.101 & 0.912 & 0.003 \\
As & 0.078 & -0.033 & 0.928 \\
Eigen value & 2.71 & 1.38 & 1.05 \\
\% Variance & 38.8 & 19.8 & 15.0 \\
\hline
\end{tabular}

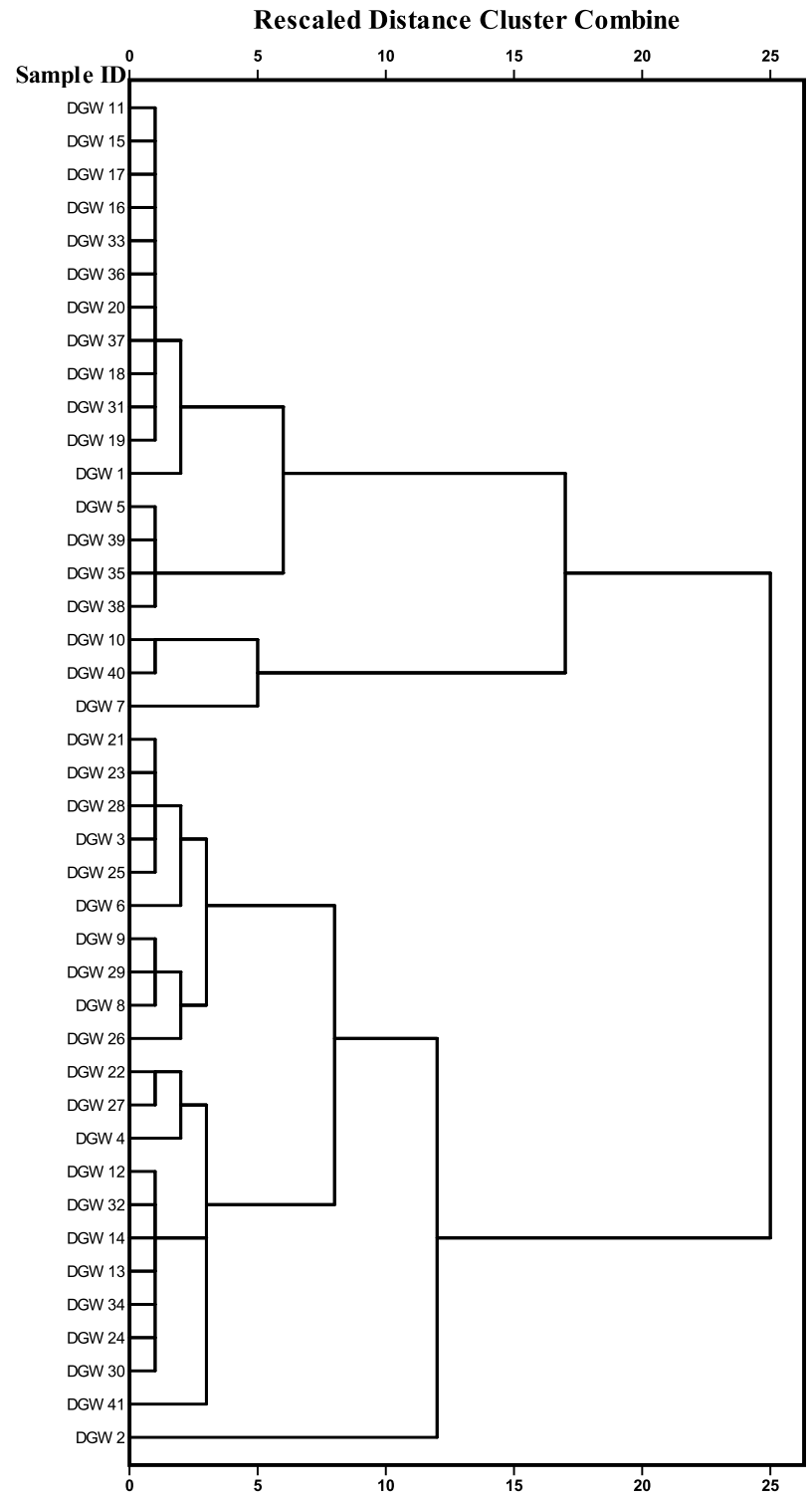

Figure 8. Dendrogram of hierarchical cluster analysis using Ward’s method. 

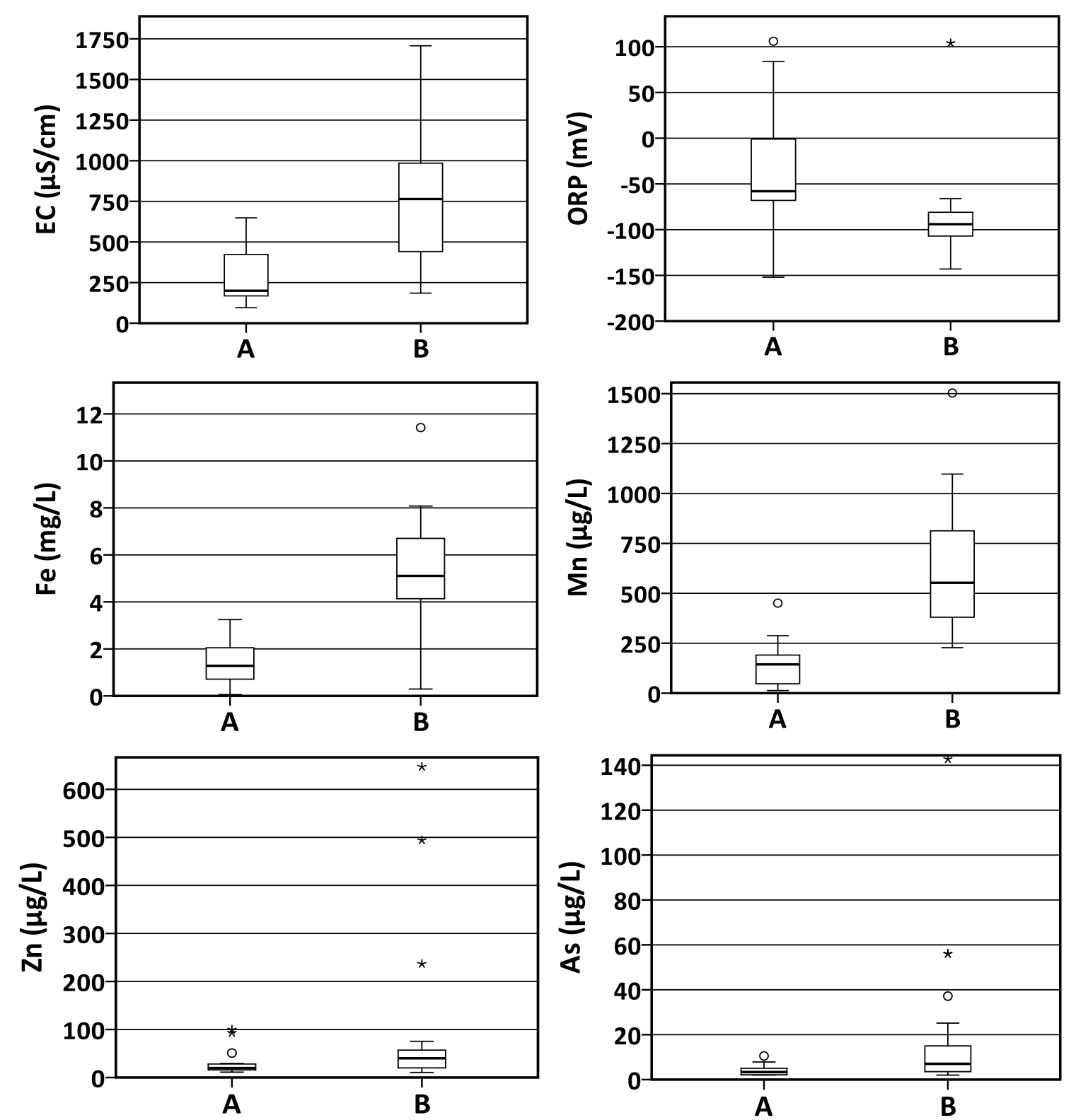

Figure 9. Box and whisker plot of EC, ORP, and metals of group (A) and (B) resulting from CA representing min, max, median, 25th, and 75th percentile.

groups of groundwater wells: Groups (A) and (B). The variations of EC, ORP, and metals in between the groups are shown in Figure 9. The groundwater wells from group (B) exhibit higher concentrations of iron, manganese, zinc, and arsenic. In addition, the group (B) observes higher EC and lower ORP value. Therefore, group (A) and group (B) are classified as groundwater of low mineralization and high mineralization, respectively. The classification of groundwater wells reveals groundwater quality varies according to natural hydrogeological conditions in the study area. Most of the groundwater wells of group (B) with high mineralization are located in CGWD, whereas many groundwater wells of group (A) with low mineralization are located in the NGWD and SGWD (Figure 10). Chapagain et al. [19] also reported similar result in the groundwater of the valley, indicating that the high mineralization in the CGWD. The high mineralization in the CGWD may be attributed to geochemical heterogeneity of the sediment in groundwater districts of the Kathmandu Valley where there is a presence of finer particles and trace elements in the sediments of central part of the valley [43]. Furthermore, the low ORP values in the CGWD would contribute to the mobilization of metals in the groundwater. 


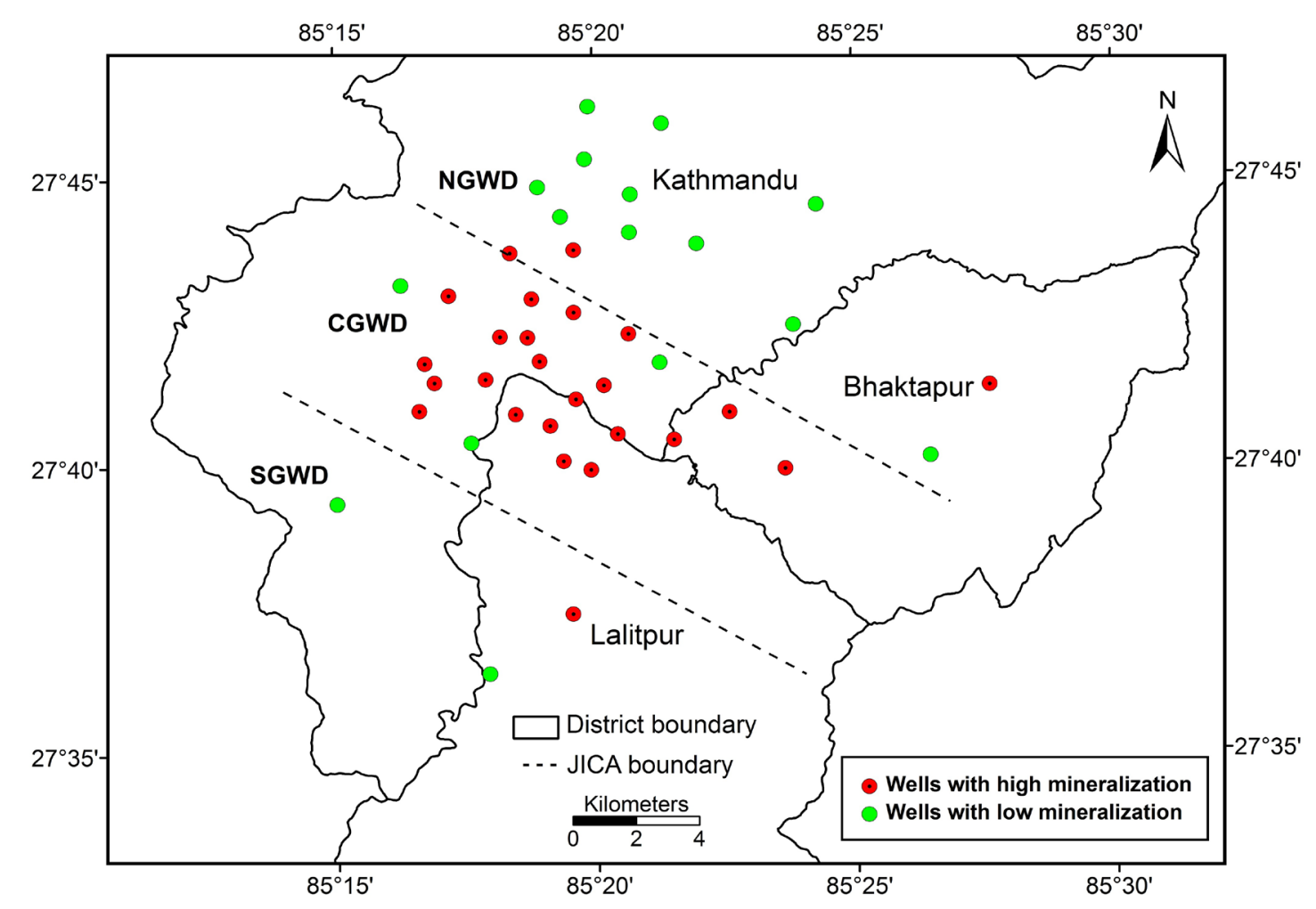

Figure 10. Classification of groundwater wells on the basis cluster analysis.

\section{Conclusion}

The study observed elevated concentrations of iron and manganese in the groundwater of the Kathmandu Valley. The occurrence of elevated concentrations of arsenic in some groundwater wells was also detected. The spatial distribution patterns demonstrated the higher concentrations of iron, manganese, and arsenic in the CGWD of the valley. Correlation analysis showed arsenic was positively correlated with iron and manganese, suggesting common geogenic origin of these metals. The ORP shows strong negative correlations with iron, manganese, and arsenic, which is attributed to reductive mobilization mechanisms of the metals in the groundwater. The results of the PCA with varimax rotation rendered the reduction of the data matrix to three important VFs. In VF 1, the high loading factors of iron and manganese reveal that these metals have common natural source of origin in groundwater. Additionally, negative loading factors of $\mathrm{pH}$ and ORP indicate that iron and manganese mobilization is favorable in low $\mathrm{pH}$ and reducing environment. The results of CA classified groundwater wells into two major groups of low and high mineralization. Many groundwater wells of the NGWD and SGWD are classified as wells of low mineralization, whereas large number of groundwater wells of the CGWD are classified as wells of high mineralization. The metals are not significantly correlated with studied time series, inferring no temporal variation of metals in the groundwater.

\section{Acknowledgements}

The authors would like to acknowledge Central Department of Environmental Science, Tribhuvan University, Nepal. The authors wish to express sincere gratitude to University Grant Commission, Nepal for a research grant. The authors also wish to thank CEMAT Water Laboratory, Kathmandu, Nepal for providing laboratory facilities for the analysis of metals using AAS.

\section{References}

[1] Garbarino, J.R., Hayes, H.C., Roth, D.A., Antweiler, R.C., Brinton, T.I. and Taylor, H.E. (1995) Heavy Metals in the Mississippi River. U. S. Geological Survey Circular 1133, Virginia. 
[2] Adriano, D.C. (2001) Trace Elements in Terrestrial Environments: Biogeochemistry, Bioavailability, and Risks of Metals. 2nd Edition, Springer-Verlag, New York. http://dx.doi.org/10.1007/978-0-387-21510-5

[3] Jarup, L. (2003) Hazards of Heavy Metal Contamination. British Medical Bulletin, 68, 167-182. http://dx.doi.org/10.1093/bmb/ldg032

[4] Marcovecchio, J.E., Botte, S.E. and Freije, R.H. (2007) Heavy Metals, Major Metals, Trace Elements. In: Nollet, L.M.L., Ed., Handbook of Water Analysis, 2nd Edition, CRC Press, London, 275-311. http://dx.doi.org/10.1201/9781420006315.ch11

[5] Turkdogan, M.K., Kilicel, F., Kara, K., Tuncer, I. and Uygan, I. (2003) Heavy Metals in Soil, Vegetables and Fruits in the Endemic Upper Gastrointestinal Cancer Region of Turkey. Environmental Toxicology and Pharmacology, 13, 175179. http://dx.doi.org/10.1016/S1382-6689(02)00156-4

[6] Mitchell, E., Frisbie, S. and Sarkar, B. (2011) Exposure to Multiple Metals from Groundwater-A Global Crisis: Geology, Climate Change, Health Effects, Testing and Mitigation. Metallomics, 3, 874-908. http://dx.doi.org/10.1039/c1mt00052g

[7] Hashim, M.A., Mukhopadhyay, S., Sahu, J.N. and Sengupta, B. (2011) Remediation Technologies for Heavy Metal Contaminated Groundwater. Journal of Environmental Management, 92, 2355-2388. http://dx.doi.org/10.1016/j.jenvman.2011.06.009

[8] Appelo, C.A.J. and Postma, D. (2005) Geochemistry, Groundwater and Pollution. 2nd Edition, A. A. Balkema Publishers, Amsterdam. http://dx.doi.org/10.1201/9781439833544

[9] Namaghi, H.H., Karami, G.H. and Saadat, S. (2011) A Study on Chemical Properties of Groundwater and Soil in Ophiolitic Rocks in Firuzabad, East of Shahrood, Iran: With Emphasis to Heavy Metal Contamination. Environmental Monitoring and Assessment, 174, 573-583. http://dx.doi.org/10.1007/s10661-010-1479-3

[10] CBS (2012) National Population and Housing Census 2011. National Report, Volume 1, NPHC 2011. Central Bureau of Statistics, Kathmandu.

[11] Acres International (2004) Optimizing Water Use in Kathmandu Valley (ADB-TA) Project. Final Report. Acres International in Association with Arcadis Euroconsult Land and Water Product Management Group, East Consult (P) Ltd. and Water Asia (P) Ltd.

[12] ICIMOD (2007) Kathmandu Valley Environment Outlook. International Centre for Integrated Mountain Development, Kathmandu.

[13] Khadka, M.S. (1993) The Groundwater Quality Situation in Alluvial Aquifers of the Kathmandu Valley, Nepal. AGSO Journal Australian Geology \& Geophysics, 14, 207-211.

[14] Jha, M.G., Khadka, M.S., Shrestha, M.P., Regmi, S., Bauld, J. and Jacobson, G. (1997) The Assessment of Groundwater Pollution in Kathmandu, Nepal. Report on Joint Nepal-Australia Project, 1995-96. Australian Geological Survey Organization, Canberra.

[15] Khatiwada, N.R., Takizawa, S., Tran, T.V.N. and Inoue, M. (2002) Groundwater Contamination Assessment for Sustainable Water Supply in Kathmandu Valley, Nepal. Water Science and Technology, 46, 147-154.

[16] JICA/ENPHO (2005) Arsenic Vulnerability in Groundwater Resources in Kathmandu Valley. Final Report. Japan International Cooperation Agency/Environment and Public Health Organization, Kathmandu.

[17] Warner, N.R., Levy, J., Harpp, K. and Farruggia, F. (2008) Drinking Water Quality in Nepal’s Kathmandu Valley: A Survey and Assessment of Selected Controlling Site Characteristics. Hydrogeology Journal, 16, 321-334. http://dx.doi.org/10.1007/s10040-007-0238-1

[18] Chapagain, S.K., Shrestha, S., Nakamura, T., Pandey, V.P. and Kazama, F. (2009) Arsenic Occurrence in Groundwater of Kathmandu Valley, Nepal. Desalination and Water Treatment, 4, 248-254. http://dx.doi.org/10.5004/dwt.2009.492

[19] Chapagain, S.K., Pandey, V.P., Shrestha, S., Nakamura, T. and Kazama, F. (2010) Assessment of Deep Groundwater Quality in Kathmandu Valley Using Multivariate Statistical Techniques. Water, Air, \& Soil Pollution, 210, 277-288. http://dx.doi.org/10.1007/s11270-009-0249-8

[20] Shrestha, S.M., Rijal, K. and Pokhrel, M.R. (2012) Heavy Metals in Groundwater Resources of Kathmandu Valley, Nepal. Journal of Nepal Geological Society, 44, 67-76.

[21] Yoshida, M. and Igarashi, Y. (1984) Neogene to Quaternary Lacustrine Sediments in the Kathmandu Valley, Nepal. Journal of Nepal Geological Society, 4, 73-100.

[22] Shrestha, S.D., Karmacharya, R. and Rao, G.K. (1996) Estimation of Groundwater Resources in Kathmandu Valley, Nepal. Journal of Groundwater Hydrology, 38, 29-40. http://dx.doi.org/10.5917/jagh1987.38.29

[23] JICA (1990) Groundwater Management Project in the Kathmandu Valley. Final Report to Nepal Water Supply Corporation, Japan International Cooperation Agency, Kathmandu. 
[24] Sakai, T., Gajurel, A.P., Tabata, H. and Uprety, B.N. (2001) Small Amplitude Lake-Level Fluctuations Recorded in Aggrading Deltaic of the Upper Pleistocene Thimi and Gokarna Formations, Kathmandu Valley, Nepal. Journal of Nepal Geological Society, 25, 43-52.

[25] Dixit, A. and Upadhya, M. (2005) Augmenting Groundwater in Kathmandu Valley: Challenges and Possibilities. Report to Nepal Water Conservation Foundation, Kathmandu.

[26] APHA-AWWA-WEF (2005) Standard Methods for the Examination of Water and Wastewater. 21st Edition, American Public Health Association, American Water Works Association, Water Environment Federation, Washington DC.

[27] Wunderlin, D.A., Pilar, D.M.D., Valeria, A.M., Fabiana, P.S., Cecilia, H.A. and Angeles, B.M.D.L. (2001) Pattern Recognition Techniques for the Evaluation of Spatial and Temporal Variations in Water Quality. A Case Study: Suquia River Basin (Cordoba-Argentina).Water Research, 35, 2881-2894. http://dx.doi.org/10.1016/S0043-1354(00)00592-3

[28] Singh, S.K., Singh, C.K., Kumar, K.S., Gupta, R. and Mukherjee, S. (2009) Spatial-Temporal Monitoring of Groundwater Using Multivariate Statistical Techniques in Bareilly District of Uttar Pradesh, India. Journal of Hydrology and Hydromechanics, 57, 45-54. http://dx.doi.org/10.2478/v10098-009-0005-1

[29] Massart, D.L., Vandeginste, B.G.M., Deming, S.N., Michotte, Y. and Kaufman, L. (1988) Chemometrices: A Textbook. Elsevier, Amsterdam.

[30] Wenning, R.J. and Erickson, G.A., (1994) Interpretation and Analysis of Complex Environmental Data Using Chemometric Methods. Trends in Analytical Chemistry, 13, 446-457. http://dx.doi.org/10.1016/0165-9936(94)85026-7

[31] Laaksoharju, M., Skarman, C. and Skarman, E. (1999) Multivariate Mixing and Mass Balance (M3) Calculations, a New Tool for Decoding Hydrogeochemical Information. Applied Geochemistry, 14, 861-871. http://dx.doi.org/10.1016/S0883-2927(99)00024-4

[32] Helena, B., Pardo, R., Vega, M., Barrado, E., Fernandez, J.M. and Fernandez, L. (2000) Temporal Evolution of Groundwater Composition in an Alluvial Aquifer (Pisuerga River, Spain) by Principal Component Analysis. Water Research, 34, 807-816. http://dx.doi.org/10.1016/S0043-1354(99)00225-0

[33] Liu, C.W., Lin, K.H. and Kuo, Y.M. (2003) Application of Factor Analysis in the Assessment of Groundwater Quality in a Black Foot Disease Area in Taiwan. The Science of the Total Environment, 313, 77-89. http://dx.doi.org/10.1016/S0048-9697(02)00683-6

[34] Singh, K.P., Malik, A., Mohan, D. and Sinha, S. (2004) Multivariate Statistical Techniques for the Evaluation of Spatial and Temporal Variations in Water Quality of Gomti River (India)—A Case Study. Water Research, 38, 3980-3992. http://dx.doi.org/10.1016/j.watres.2004.06.011

[35] Cloutier, V., Lefebvre, R., Therrien, R. and Savard, M.M. (2008) Multivariate Statistical Analysis of Geochemical Data as Indicative of the Hydrogeochemical Evolution of Groundwater in a Sedimentary Rock Aquifer System. Journal Hydrology, 353, 294-313. http://dx.doi.org/10.1016/j.jhydrol.2008.02.015

[36] Yammani, S.R., Reddy, T.V.K. and Reddy, M.R.K. (2008) Identification of Influencing Factors for Groundwater Quality Variation Using Multivariate Analysis. Environmental Geology, 55, 9-16. http://dx.doi.org/10.1007/s00254-007-0958-5

[37] Davis, J.C. (1986) Statistics and Data Analysis in Geology. 2nd Edition, John Wiley \& Sons, New York.

[38] Hem, J.D. (1985) Study and Interpretation of Chemical Characteristics of Natural Water. 3rd Edition, U.S. Geological Survey, Water Supply Paper 2254.

[39] Kim, M.J., Nriagu, J. and Haack, S. (2002) Arsenic Species and Chemistry in Groundwater of Southeast Michigan. Environmental Pollution, 120, 379-390. http://dx.doi.org/10.1016/S0269-7491(02)00114-8

[40] Smedley, P.L. and Kinniburgh, D.G. (2013) Arsenic in Groundwater and the Environment. In: Selinus, O., Ed., Essential of Medical Geology, Springer, Dordrecht, 279-310. http://dx.doi.org/10.1007/978-94-007-4375-5_12

[41] Dill, H.G., Khadka, D.R., Khanal, R., Dohrmann, R., Melcher, F. and Busch, K. (2003) Infilling of the Younger Kathmandu-Banepa Intermontane Lake Basin during the Late Quaternary (Lesser Himalaya, Nepal): A Sedimentological Study. Journal of Quaternary Science, 18, 41-60. http://dx.doi.org/10.1002/jqs.726

[42] WHO (2011) Guidelines for Drinking-Water Quality. 4th Edition, World Health Organization, Geneva.

[43] Gurung, J.K., Ishiga, H., Khadka, M.S. and Shrestha, N.R. (2007) The Geochemical Study of Fluvio-Lacustrine Aquifers in the Kathmandu Basin (Nepal) and the Implications for Mobilization of Arsenic. Environmental Geology, 52, 503-517. http://dx.doi.org/10.1007/s00254-006-0483-y

[44] Fujii, R. and Sakai, H. (2001) Palynological Study on the Drilled Sediments from the Kathmandu Basin and Its Paleoclimatic Significances. Journal of Nepal Geological Society, 25, 53-61.

[45] Daughney, C.J. (2003) Iron and Manganese in New Zealand’s Groundwater. Journal of Hydrology (New Zealand), 42, $11-26$. 
[46] Pierce, M.L. and Moore, C.B. (1982) Adsorption of Arsenite and Arsenate on Amorphous Iron Hydroxide. Water Research, 16, 1247-1253. http://dx.doi.org/10.1016/0043-1354(82)90143-9

[47] Smedley, P.L. and Kinniburgh, D.G. (2002) A Review of the Source, Behavior and Distribution of Arsenic in Natural Waters. Applied Geochemistry, 17, 517-568. http://dx.doi.org/10.1016/S0883-2927(02)00018-5

[48] Anawar, H.M., Akai, J., Komaki, K., Terao, H., Yoshioka, T., Ishizuka, T., Safiullah, S. and Kato, K. (2003) Geochemical Occurrence of Arsenic in Groundwater of Bangladesh: Sources and Mobilization Processes. Journal of Geochemical Exploration, 77, 109-131. http://dx.doi.org/10.1016/S0375-6742(02)00273-X

[49] McArthur, J.M., Banerjee, D.M., Hudson-Edwards, K.A., Mishra, R., Purohit, R., Ravenscroft, P., Cronin, A., Howarth, R.J., Chatterjee, A., Talukder, T., Lowry, D., Houghton, S. and Chadha, D.K. (2004) Natural Organic Matter in Sedimentary Basins and Its Relation to Arsenic in Anoxic Groundwater: The Example of West Bengal and Its Worldwide Implications. Applied Geochemistry, 19, 1255-1293. http://dx.doi.org/10.1016/j.apgeochem.2004.02.001

[50] Biswas, A., Majumder, S., Neidhardt, H., Halder, D., Bhowmick, S., Mukherjee-Goswami, A., Kundu, A., Saha, D., Berner, Z. and Chatterjee, D. (2011) Groundwater Chemistry and Redox Processes: Depth Dependent Arsenic Release Mechanism. Applied Geochemistry, 26, 516-525. http://dx.doi.org/10.1016/j.apgeochem.2011.01.010

[51] Smith, L.A., Means, J.L., Chen, A., Alleman, B., Chapman, C.C., Tixier Jr., J.S., Brauning, S.E., Gavaskar, A.R. and Royer, M.D. (1995) Remedial Options for Metals-Contaminated Sites. Lewis Publishers, Boca Raton.

[52] Katsoyiannis, I.A. and Katsoyiannis, A.A. (2006) Arsenic and Other Metal Contamination of Groundwaters in the Industrial Area of Thessaloniki, Northern Greece. Environmental Monitoring and Assessment, 123, 393-406. http://dx.doi.org/10.1007/s10661-006-9204-y

[53] Ayotte, J.D., Nolan, B.T., Nuckols, J.R., Cantor, K.P., Robinson Jr., G.R., Baris, D., Hayes, L., Karagas, M., Bress, W., Silverman, D.T. and Lubin, J.H. (2006) Modeling the Probability of Arsenic in Groundwater in New England as a Tool for Exposure Assessment. Environmental Science and Technology, 40, 3578-3585. http://dx.doi.org/10.1021/es051972f

[54] Dzombak, D.A. and Morel, F.M.M. (1990) Surface Complexation Modeling: Hydrous Ferric Oxide. John Wiley \& Sons, New York.

[55] Gurung, J.K. (2007) Geochemical Studies of Sediments and Water, and Implications for Mobilization of Arsenic into Groundwater in Nepal and Japan. PhD Dissertation, Shimane University, Matsue.

[56] Filipek, L.H. and Owen, R.M. (1979) Geochemical Associations and Grain-Size Partitioning of Heavy Metals in Lacustrine Sediments. Chemical Geology, 26, 105-117. http://dx.doi.org/10.1016/0009-2541(79)90033-0

[57] Singh, A.K., Hasnain, S.I. and Banerjee, D.K. (1999) Grain Size and Geochemical Partitioning of Heavy Metals in Sediments of the Damodar River-A Tributary of the Lower Ganga, India. Environmental Geology, 39, 90-98. http://dx.doi.org/10.1007/s002540050439

[58] Schurch, M., Edmunds, W.M. and Buckley, D. (2004) Three-Dimensional Flow and Trace Metal Mobility in Shallow Chalk Groundwater, Dorset, United Kingdom. Journal of Hydrology, 292, 229-248.

http://dx.doi.org/10.1016/j.jhydrol.2004.01.004 